\title{
The CHILD AS “CUSTODE DELLA MEMORIA FUTURA"1: THE MAN WHO WILL COME AND THE MASSACRE OF MARZABOTTO
}

\section{MiLLICENT MaRCUS}

Summary: By choosing Martina, an 8 year old peasant child, to be the focalizer of the Marzabotto massacre, Diritti makes possible a new historiography, shorn of the ideological appropriations to which this atrocity had lent itself over the years. In her determination to save her newborn brother, and her breaking of the fierce silence that she had maintained throughout the duration of the film, Martina signals her will to bear witness to the horror, and to endow her sibling, symbolically the New Man of postwar rebirth, with the power to redeem the course of events by guaranteeing, in Diritti's words, "che in futuro una cosa del genere non avvenga più."

"Stamattina a San Martino, ne hanno trovati altri quaranta" (this morning, at San Martino, they found another forty of them) the anti-Fascist priest Don Fornasini tells his mother in the aftermath of the strage di Marzabotto - the Nazi extermination of 770 civilians living on the slopes of Monte Sole to the southwest of Bologna in the region of Emilia Romagna.2 "Li abbiamo seppelliti tutti insieme, mamma, non si poteva rischiare" (we buried them all together, Mama, we couldn't take any risks). In making The Man Who Will Come, a fiction film which scrupulously follows the historical record, Giorgio Diritti attempts to give symbolic burial to the mass victims of one of the largest civilian slaughters to take place on the battle fronts of Western Europe during the Second World War. Significantly, one reviewer of The Man Who Will Come labeled the film an "epicedium"3_an ancient Greek funeral lament, chanted by a chorus—in

1 "The custodian of future memory." See Paolo D'Agostini,, "Cronaca di una strage per non dimenticare." Uomini d'ogni tempo, 46.

2 Though Marzabotto is the name of only one of the municipalities in the zone of Monte Sole whose populations were exterminated by the Nazis between Sept. 29 and Oct. 5 1944, it was the largest, and has therefore come to stand, by antonomasia, for all the areas included in the Nazi round-up and slaughter during those days. The other municipalities that were struck included Grizzana and Monzuno, all in the area of Monte Sole.

3 Roberto Chiesi, "Un film 'inattuale”, 8. 
a characterization which accounts for the central importance of the soundtrack, as well as for the film's overall identity as a rite of mourning.

In order to scale-down the mind-numbing enormity of the slaughter, so that it ceases to remain in the realm of statistical abstraction and becomes a concrete human event whose victims invite our identification and whose loss we mourn, Diritti presents an imaginary family of peasant farmers living in the area of Monte Sole, and raises their plight to the level of tragic exemplarity. Despite the fictional origin of its characters, the film achieves documentary force as a result of Diritti's extensive research and his painstaking efforts to recreate with an "attention bordering on the maniacal," the historical events of the atrocity within the material context of rural life in Emilia Romagna during the mid-1940's. ${ }^{4}$

One of the challenges in reconstructing a well-known and highly fraught historical episode many decades after its occurrence, is to purge the event of an a posteriori, ideologically charged perspective and to give it the immediacy of those who experienced it in real time. 5 In pursuit of this zero-degree historical awareness, Diritti chooses as his vehicle the eight year-old Martina, daughter of the Palmieri family. But before settling on this focalizing character, Diritti had considered two other groups from which such a figure could emerge: the Stella Rossa Brigade of partisans active in the Monte Sole area, and members of the local clergy who harbored anti-Fascist sympathies. ${ }^{6}$ Because either of these options would privilege ideology per se, Diritti's zerodegree strategy was best served by the peasants' perspective, with its emphasis on survival and natural justice at the expense of political platforms and ideological certainties. "Perchè non restano a casa loro?" (Why don't they just stay home?) Martina's father Armando asks his landlord, who feels compelled to remain in the Nazis' good graces. "La storia è piena di guerra" (History is full of war) the landlord responds. "La storia? Chi se ne frega della storia e di chi la fa?" (History? Who cares about history and those who make it) counters Armando. "Diventano tutti importanti chi ammazza e chi ruba ai pove-

4 Excerpted from the interview with Daniela Basso in Uomini d'ogni tempo, 30. See also Giorgio Diritti and Alessandra De Luca, "Sul Set" 111, and Goffredo Fofi, "Prima e dopo la strage," 13. The focus on quotidianità is a constant in Diritti's self-commentary. See, for example, "L'uomo che verrà. Un film su Monte Sole," 10 and the interview with Daniela Basso, both in 22, 23, both in Uomini d'ogni tempo.

5 See Fabio Ferzetti in "Tante emozioni per soffiar via la polvere della Storia," in Uomini d'ogni tempo, 55. For related observations, see Gianluca Arnone, 68.

6 See the interview by Gabriele Romagnoli, "Siamo morti anche noi," in Uomini d'ogni tempo, 39-40. 
retti. Che storia è questa?" (Those who kill and rob the poor are all the ones who become important. What kind of history is that?)

Though children have served a strategic focalizing function throughout the canon of Italian cinema as observers of adult incivility, social injustice, and the ravages of war (e.g. The Children Are Watching Us, Bicycle Thief, The Sky Is Falling, respectively), Martina's focalization both reinforces this trend and departs from it in a stunning way. Like Pricò, Bruno, Penny and Baby, Martina brings a childhood vulnerability to her perspective which invites us to set aside any protective cynicism or historical knowledge that might cloud our direct and appalled view of her story's contents. As spectators whose gaze is modeled on Martina's, we share the child's innate sense of the rightness and wrongness of things, and are brought to a naïve, and therefore ethically pure, position of judgment with respect to the war-time horrors that the film recounts. "Lo sguardo di Martina," explains screenwriter Tania Pedroni, "è capace di stupirsi, di incantarsi, ma anche forse di non trovare normale quello che non dovrebbe essere normale . . . Ci sono tante cose con cui forse arriviamo a convivere ma che dovrebbero invece continuare a scandalizzarci, ad indignarci, a farci ribellare" (Martina's gaze is able to surprise her, to enchant her, but also perhaps to not find normal what shouldn't be normal . . . There are so many things with which we manage to coexist but which should instead continue to scandalize us, to make us indignant, to make us rebel). ${ }^{7}$

While sharing the ethical patrimony of her predecessors' childhood view-points, Martina's radically differs from theirs in that she suffers from a disability which makes particular claims on the audience's attention: she is mute, and both the cause and the effect of this speechlessness give her special powers over the shape of the narrative as well as its hold on our imaginations. Not until forty minutes into the film do we learn the origin of her impairment - she was struck dumb upon the death of a newborn baby brother who expired in her arms - a tragedy for which she brutally and irrationally blames herself. Martina's silence throughout the film-her refusal to produce the spoken word, has condemned her to a kind of perpetual infancy, understood etymologically as infans: incapable of speech. Yet we soon learn that she has a rich and complex inner life, as evidenced by the verses that she composes as her Christmas offering to the baby Jesus. While the two children who precede her recite verses of the most simplistic and perfunctory sort, Martina, the mute, gives voice to a more pro-

7 Quoted from the interview on http://www.youtube.com/watch?v=6-KnEMbquAw. My thanks to Patrizia Bettella for bringing this valuable documentary to my attention. 
found sense of self through her writing (as read aloud by the parish Perpetua).

\author{
Voglio donarti il cuore \\ $\mathrm{O}$ mio signore. \\ Ma tu degli angioletti \\ Che in ciel ti fan corona \\ Ispirami gli affetti. \\ Fammi come essi buona \\ La mamma e il babbo mio \\ Rendi felici o Dio.
}

(I want to give you my heart, oh Lord, but breathe into me the feelings of the angels in heaven who crown you. Make me good like them, and make my Mom and Dad happy, oh God).

What is most striking for our purposes is Martina's deep need for expiation and her belief that she is somehow responsible for alleviating her parents' unhappiness. The answer to this prayer will be the birth of a new baby brother, whose life she will preserve as compensation for the infant whose death in her arms left her guilt-stricken and bereft of speech.

This new child will be her redeemer, a Christ figure whose identity is made explicit in one of the film's earliest scenes, when Lena, Martina's mother, visits a shrine dedicated to the pregnant Madonna. ${ }^{8}$ After leaving an offering of dried flowers and uttering a silent prayer, Lena caresses the swollen belly of the image in a shot fraught with significance for our relationship to the language of Diritti's film. Lena's inwardness in this scene, her devotional relationship to the image in whose material as well as spiritual reality she believes, tells us not only a great deal about peasant piety, but also about the kind of reverential act of re-evocation through which Diritti has depicted this world. On the meta-level of the film's reception, it follows that the sacrality of Lena's bond with the painted image should serve as a model for the solemnity and reverence with which we spectators should experience the imagery of the film to come.

No sooner does Lena complete her act of prayer than the title of the film appears, giving The Man Who Will Come a distinctly theological cast. The man who is to come is the longed-for male child, a savior figure who promises resurrection of the family's future, after the death of the first-born son. But the semantic insistence on the adulthood of this much-desired offspring projects the hope into a future understood in generational terms.

8 On the Christological role of the infant, see the review by Michele Anselmi. 
This child will grow into the proverbial New Man, the postwar generation bearing the daunting responsibility for national rebirth in the wake of the Fascist ventennio (twenty years), the catastrophic alliance with Germany, Italy's fiascos on the WWII battle front, the nightmare of Nazi occupation and the Allied campaign of Liberation. At the end of the film, Martina recovers her powers of speech, and this "miracle" must be understood in relation to her baby brother's generational significance, as well as to her own personal logic of atonement. Though such logic would lead us to expect her withdrawal into a state of permanent silence, if not outright catatonia, given the mega-death that she has witnessed, Martina's reemergence from muteness makes sense as her reward for keeping this second brother alive. One ironic outcome of her return to verbal utterance at the end of the film is that now she must bear witness to the storia nefandaliterally unspeakable history - of Marzabotto. It is this story which she must transmit to the baby, if the Italian New Man is to symbolically "work through" historical trauma in order to stave off its recurrence. ${ }^{9}$

Diritti is not the first to cast an infant as the receiver of historical witness. An important, and complex precedent for such a choice may be found in the Tavianis' Night of the Shooting Stars (1982), whose frame narrative involves a woman's reminiscence of her own childhood experiences during the Allied liberation of Tuscany. Only in the final frames of the film do we learn that her listener is a sleeping baby in an ending of considerable ambiguity, suggesting on the one hand the futility of the woman's attempt at intergenerational transmission, or on the other, that this will be the first installment in a series of historical retellings. Benigni's Life Is Beautiful (1997), may be seen to adopt a similar framing device in which the chronicle of childhood survival and witness to atrocity is framed by a voice-over narration addressed to the speaker's own son or daughter. In the case of Life Is Beautiful such intergenerational transmission may reach beyond the film's fictional borders to its autobiographical source in Benigni's own childhood reception of his father's harrowing testimony about the experience of internment in a Nazi concentration camp after his capture as a prisoner of war.

For obvious reasons, Martina cannot emerge from silence into fullfledged adult discourse in Diritti's final scene. Instead she undertakes a vocal performance entirely appropriate to its infant listener-a lullaby, sung to soothe the baby as she herself had been soothed by her own mother, in a sign of the girl's will to establish continuity with a world on the verge of extinc-

9 On the need to therapeutically overcome historical trauma through a collective mourning process in order to build a healthy, cohesive, and forward-moving social identity, see Eric Santner. 
tion. To memorialize that world - to preserve its memory cinematically in light of its subsequent disappearance-Diritti exploits film's identity as a "time medium" to great effect. Throughout The Man Who Will Come, Diritti posits a clash between two rival temporalities - that of the quotidianità of peasant life, and that of the grand sweep of History. ${ }^{10}$ In the scene immediately following its title sequence, the film opens onto an archaic world, governed by the rhythms of the Bakhtin's "folkloric chronotope," unbound to any specific moment in historical time. ${ }^{11} \mathrm{~A}$ liquid is being ladled from one cauldron into another over a rustic hearth, and a little girl is being scolded by her grandmother for being unpresentable in church in her threadbare state. Now a written caption appears to catapult this scene into historical linearity announcing that the action takes place in December, 1943-in the throes of the Nazi occupation. Taking as its starting point the final days of that year and ending with the events of Sept. 29-October 5 of 1944, the film traces a full cycle of seasons and chronicles the agrarian activities appropriate to them: tethering the grape vines, slaughtering a pig, gathering the hay, etc. In keeping with the film's theological dimension, two religious observances punctuate the flow of time: Christmas and First Communion. But the most significant measure of temporality within the film is that of human gestation - the narrative arc begins with a discreet scene of love-making-whose unobtrusiveness, however, does not prevent Martina from witnessing itand comes to a conclusion with the nearly simultaneous birth of the baby and the Nazi round-up of the civilian population of Monte Sole. As this concurrence suggests, historical time enters the natural temporality of the peasant world to shatter its integrity, so that the normal progress of post-partum life, including not only maternal care but also the attentions of a rich network of familial and communal relations, must be solely entrusted to an eight year old girl.

In addition to its characteristic temporality, the chronotope of peasant life in The Man Who Will Come involves a corresponding spatial element, defined by a strict localism, and dominated by the contours of nature. Martina's personal relationship to the natural world is one of harmony and balance, even when the landscape seems most unforgiving, such as the scene of her early morning trek to school through the snow with her bare legs

10 On the clash of temporalities in Diritti's film, see the directors comments in "L’uomo che verrà. Un film su Monte Sole," 10. See also Fabio Ferzetti, "Tante emozioni per soffiar via la polvere della Storia, 55, both in Uomini d'ogni tempo.

11 On the folkloric chronotope, see Mikhail Bakhtin, The Dialogic Imagination. Bakhtin defines chronotope as "the intrinsic connectedness of temporal and spatial relationships that are artistically expressed in literature" (84). 
exposed to the cold. As the camera lingers on her for an inordinately long time, the effect is neither one of pathos nor disbelief, but of curiosity about yet one more element of the peasants' quotidianità. A more cordial landscape envelops Martina in two important scenes, one in which she glides among green fields wearing the new dress and white veil of her First Communion, and the other in early spring, when we hear Martina actually speak, in the form of a voice-over reciting the words of an essay she has written for an assignment at school. It is as if this early flowering of nature had prompted in her a profound and politically charged expression of self. As the camera shows her walking through the countryside, we hear Martina wondering why the Germans don't stay home with their children, and why they speak another language. She is perplexed by the term "enemy", having no precise idea to whom it refers. Most importantly, Martina's writing bespeaks the local peasants' view of the Resistance (as if to say "we will help them even if we cannot leave our land and join their ranks").

With the exception of the few written entrees into Martina's thoughts, the rest of the film requires us to intuit her reactions to the surrounding world. The child's lack of verbal communication with others, her solitude and her inwardness serve to focus our attention on events themselves, and then to ponder their impact on this intensely observant, somewhat mysterious, and highly vulnerable subjectivity. "Il mutismo di Martina è sintomo di una grande sensibilità allo sguardo, all'osservazione, (Martina’s muteness is a symptom of a great sensitivity of the gaze) Diritti explains. "È una dimensione, in uno stato di mancanza, di maggiore percettibilità e attenzione. Nel film, il suo silenzio si fa racconto." (It is a dimension, in a state of lack, of superior perceptiveness and attention. In the film, her silence becomes the story.) 12 Without verbal access to her relationships with the world, we must depend upon outward physical manifestations of it, but these lack all eloquence. Diritti's camera dwells extensively on her face, whose expression remains largely opaque, a blank screen-within-the-screen inviting us to project our own imagined reactions to her plight. Her facial expressionlessness has its bodily counterpart in the stillness and withdrawal which accompanies her moments of greatest distress. At these times, she either retreats into the barn, where she assumes a posture which seems to fold in on itself, or she perches on a bench outside the school, or farmhouse in absolute immobility. It is as if her muteness extended beyond the organs of speech to envelope her entire being in a cloak of impassivity.

To compensate for Martina's silence, the film's soundtrack assumes a

12 See the interview with Daniela Basso in Uomini d'ogni tempo, 31. 
place of special prominence, indicating her state of mind during moments of acute anxiety, or the rare ones of contentment. ${ }^{13}$ In two sequences of unalloyed pleasure on the part of Martina, the musical sound track is dominated by what I would call the "idyllic motif." We hear it during Martina's voice-over recitation of the school essay, against the background of her walk through the flowering meadow of early spring. During the sequence of Martina's first communion, it forms a musical bridge across three scenes, from the walk to church in her lovely new dress and veil, to the celebration of the Mass, to the children's frolic after the service. The fact that this motif accompanies the actual scene of the church service itself, taking the place of prayer, hymns, and other appropriate ecclesiastical sounds, suggests that for the child, the religious experience is not qualitatively unique, but of a piece with her pleasure in nature and in play.

Alas, the musical manifestations of extreme anxiety and inner turmoil far outweigh those of Martina's delight. Characterized by the high-pitched chanting of what seem to be children's voices perceived in a delirium, this motif is first heard briefly and faintly after Martina is harassed by two schoolmates for her "otherness," and again, more obtrusively, as she and another child watch the partisan ambush which kills three occupants of a Nazi jeep. Most dramatically, this sound-track seizes our attention as Martina runs away in horror after witnessing the execution of a German soldier - the one revealed to be the "softest" and sweetest of his cohort ${ }^{14}$ by the partisan who had previously announced his refusal to shoot another man. The film's musical rendering of agitation verging on hallucination is accompanied by jerky, hand-held camera movements which mimic the instability of Martina's visual field as she races home from the execution site to find Lena in the kitchen, but is unable to give vent to her inner crisis through speech. This hallucinatory motif, which had originally been confined to Martina's subjectivity, is generalized to all the children as they flee their temporary lodging in the schoolhouse. It will ultimately merge with the film's "theme song," chanted by adult voices, when the victims are led to the site of impending slaughter in the cemetery of Casaglia.

But the most telling sound effect, because most indicative of Martina's power to shape the narrative and to speak for Diritti's intent in making The Man Who Will Come, is a simple ninna nanna, or lullaby, sung in Emilian

13 On Diritti's apt use of music in the film, see Goffredo Fofi, 14.

14 This soldier is the one who diffuses a very tense scene by juggling the eggs extorted from the Palmieri family, and he is the one who is visibly moved by the sharing of bread and soup with the peasant community. 
dialect, at the beginning, middle, and end of the film. It first emerges in the earliest barn scene, where Martina takes refuge after her ordeal of harassment, and as she withdraws into a posture of self-enclosure, a few strains of the song can be heard. But she is not vocalizing them, and we are therefore led to assume that this is her inner song of consolation. Later the ninna nanna will assume its full-fledged identity as music to lull a child to sleep, when Lena sings it to Martina as they cuddle in bed. Most momentously, the song recurs at the film's end as Martina softly produces it - her first vocalization since the death of her baby brother - to soothe the new infant whose life she has been able to save. In so doing, she signals her transformation into a mother figure, and her assumption of a responsibility that goes beyond the film's narrative bounds to include her role as witness dedicated to the transmission of memory to post-war generations. ${ }^{15}$ The coralità of much of the film's music, and the source of the lullaby in the folk-culture of the Emilian countryside, suggest that this entire community will be speaking through Martina's testimony - that she will be its custodian of memory.

There is another musical motif which transcends any individual character's subjectivity and comes to stand as both the choral expression of an entire community lost to history, and as the film's own formal commentary on that loss. I have called this music the film's theme song, and it is a dirge. Significantly, this music is first heard during the wake over the body of Antonio, the lover of Maria, executed by hanging for his partisan loyalties. During the film's second half, it will recur and with increasing frequency as the Nazi genocidal plan unfolds, but with the addition of a choral element. As such it takes on the air of hymnody, of sacred music, in keeping with the burial rites which Diritti's film symbolically enacts. During the final frames of The Man Who Will Come, as the end credits roll, two seemingly antithetical musical forms alternate- the lullaby and the dirge- - suggesting that the only way to commemorate and mourn the dead of Marzabotto is to usher in new lives committed to building a world free of war and its attendant atrocities. ${ }^{16}$

15 Though several critics have taken issue with this "happy ending" as a concession to sentimentality, I find it essential to Diritti's testimonial purpose in making The Man Who Will Come, as does Attilio Coco in "La trasparenza della Storia" 34. For another cogent defense of the ending, see Eliana Elia's review, 74. Among the ending's detractors, see Roberto Chiesi, "Un film 'inattuale," 8, and again in his Segnocinema review of the film on page 34.

16 For Diritti's comments on the "collateral damage" caused by war, and on the scarce media attention to it, see the interview with Daniela Basso in Uomini d'ogni tempo, 26. 
As the focalizer of the Marzabotto tragedy, and its conduit to future generations, Martina comes to embody the testimonial impulse that inspired the very making of The Man Who Will Come. Such terms as "necessity, "urgency," "responsibility," "moral commitment", and "need" abound in Diritti's public statements about what drove him to undertake this daunting project. ${ }^{17}$ As a reader of historical texts concerning the massacre, Diritti was left with a powerful impression "che bisognava fare qualcosa: tale drammaticità non poteva restare solo nei numeri, o nei libri di storia, aveva bisogno di essere raccontata" (that it was necessary to do something: such drama could not be consigned to numbers, or to history books, it had to be told as a story). During the next phase of Diritti's research-his personal encounters with contemporary residents of Monte Sole-this impulse gained emotional and ethical momentum, "come se i familiari delle vittime e i superstiti mi avessero dato la loro memoria, chiedendomi di trasferirla ad altri, e penso che il film abbia questa forza in una volontà di diffondere un messaggio di pace" (as if the family members of the victims and the survivors had given me their memory, asking me to transfer it to others, and I think that the film has this force of a will to spread a message of peace). ${ }^{18}$ As the direct or second-generation witnesses to the events of Monte Sole, his interlocutors are issuing a powerful plea-that Diritti testify, in turn, to this history, that he use his medium to "trasferirla ad altri" in a way which would instill identification with the victims, a sense of grief for their loss, an assumption of moral responsibility toward the historical currents which led to this horrific past, and a commitment to actively intervene in the course of public events to preclude future occurrences. In his very choice of the film's title, Diritti envisions "the one who is to come" as the receiver of this testimony, the repository of historical awareness and of its built-in "messaggio di pace."

Within the film, Diritti's didacticism is set in stark opposition to the Nazi's understanding of "educazione," as voiced by the SS commander-historically based on Walter Reder-who authorized the genocidal campaign. "Tutti noi siamo quello che ci hanno insegnato ad essere, è una questione di educazione" (we are all what they have taught us to be, it's a question of upbringing), he explains to the anti-Fascist priest Don Fornasini, in the aftermath of the massacre. Reder's pronouncement presents a paradox, for it serves both the Nazis nefarious purpose- to deny individual moral respon-

17 See, for example, Giorgio Diritti, "L'uomo che verrà. Un film su Monte Sole," in Uomini d'ogni tempo, 11, the interview with Daniela Basso in the same volume, 23, 25, and 29. See also "Sul set," Ciak (January 2010), page 109.

18 Quoted from the interview with Barbara Sorrentini on the Dolmen Home Video DVD. 
sibility for his and his countrymen's deeds-and Diritti's redemptive oneto posit the perfectibility of the human condition through culture. "Leducazione è significativamente alla base dell'agire dell'uomo e nello sviluppo della società civile; portare quindi in un film i fatti di Marzabotto significa mantenere vive e vigili le coscienze degli uomini e anche educare le presenti e le future generazioni affinché un domani un'altra ideologia non trasformi il senso della vita annientando le coscienze" (Education is significantly at the base of man's actions and the development of civil society; thus to present the facts of Marzabotto in a film means maintaining alive and vigilant the consciences of men and also to educate the present and future generations so that tomorrow another ideology will not transform the sense of life, annihilating consciences). ${ }^{19}$

In a further telling statement, the filmmaker could be speaking for himself when he says of his non-professional actors, many of whom had family-members involved in the massacre, "sono stati spinti da un volere morale, una volontà politica (non partitica) e dal senso civico" (they were impelled by a moral desire, by a political [but not party-driven] will and by a civic impulse). ${ }^{20}$ Reviewers have been acutely attuned to the distinction between an understanding of politics in its narrow sense, as partisanship in the pursuit of power, and in its broader sense ("senso civico") as the organization of a society around the principle of the common good. It is to this latter ideal that Diritti's film entrusts its didactic purpose-simply put, to "lavorare per la pace e rendere le persone consapevoli" (work for peace and make people aware). ${ }^{21}$ In this emphatically non-ideological, but nonetheless deeply engaged act of filmmaking, Diritti endows his work with what critics Antonello and Mussgnug have labelled "postmodern impegno," replacing a commitment to the Marxist agenda which characterized most of the engagé art of the latter $20^{\text {th }}$ century, with an ethically oriented, progressive vision for the arts in a post-ideological world. ${ }^{22}$ It is in this sense that we may see Diritti as updating the example of Ermanno Olmi, whose body of work represented an on-going alternative to ideologically driven filmmaking since the early 1960's.

19 Giorgio Diritti, “The Man Who Will Come: Un film su Monte Sole," (10-11) in Uomini d'ogni tempo. In his review of the film, Gianluca Arnone sees this as "l'unico forte ammonimento politico di un film che si sottrae per altri versi a ogni querelle nostrana," (68).

20 Giorgio Diritti and Alessandra De Luca, "Sul set" (110).

21 Ibid 09.

22 See the Introduction to Pierpaolo Antonello and Florian Mussgnug, 1-29 
Much has been made of the influence of Olmi on Diritti's career, and with good reason. ${ }^{23}$ First and foremost, Diritti was a student in "Ipotesi cinema," the film school founded by Olmi, making the younger filmmaker a direct recipient of the master's approach. Of particular relevance to The Man Who Will Come is Olmi's epic film of the Bergamasco countryside, Tree of the Wooden Clogs, (1978) which chronicled the fortunes of a single family, within the choral context of the little peasant community lodged in the same farmhouse complex, throughout a full cycle of seasons toward the end of the $19^{\text {th }}$ century. In addition to sharing a documentary focus on the quotidianità of peasant life within a set of very specific geo-temporal coordinates (including the insistence on dialect), both Olmi and Diritti make children the focal points of their films' narrations. In Tree of the Wooden Clogs, it is the young son of the Battisti family, Minek, whose academic potential sets the story in motion and whose gaze of sadness and longing brings it to a close. Furthermore, both directors elevate the religiosity of their peasant protagonists into a model for their own relationship to the worlds they represent on film, adopting a reverential stance, much as Lena had in her abovementioned visit to the shrine of the pregnant Madonna. In accordance with this shared sacralizing impulse, both films enact a Scriptural scenario - that of the Fall from a state of primal innocence and wholeness into one of guilty knowledge and exilic despair. For the Battisti family in Olmi's film, that Fall is the result of an internal force-the family's decision to send Minek to school, and thus to literally gain that knowledge which will banish them from the Eden of the archaic world from which they came. For the Palmieri family, instead, it is History which expels them from a prior state of grace, condemning them either to immediate and violent death, or to a condition of irreparable loss and the necessity of bearing witness to it. By locating the source of the Fall in external historical circumstance, rather than in humans' innate desire for knowledge, Diritti grants agency to those who would learn from history and be moved to intervene in its course. In this sense, L'uomo che verrà may be seen as updating Olmi's vision, and bringing it into alignment with the progressive, non-ideological, yet nonethe-less political currents of postmodern impegno.

Diritti builds this committed stance into the film's framing device, which foregrounds and enacts its own testimonial status as defined by the "now" of the narrating process. The film opens with a subjective camera shot that moves slowly and smoothly through a series of rooms, all containing empty beds whose disarray suggests the hasty departure of their occupants.

23 See the review by Gianluca Arnone, 68. 
After focusing on one particular bed, Diritti cuts to a reverse shot of a shorthaired, primly dressed little girl before cutting back to the bed, which is now occupied by the same girl, this time wearing long hair and a night cap. With this second cut, the film has transitioned back into the past, where it will remain until the concluding sequence, when events will have finally "caught up" to the scene which introduced the framing device. The Man Who Will Come is thus the story of its own telling, the narrative of how Martina acquired the power to bear witness to the destruction of her world.

Martina is "custode della memoria futura" wrote Paolo D'Agostini, ${ }^{24}$ and as such, her wandering through the rooms of the farmhouse during the film's opening frames literalizes the metaphor of the chambers of the mind, drawing upon the ancient rhetorical technique which dictates the assignment of items for memorization to specific rooms in an imagined house. The very gap between the fullness of the life lived in those rooms, as conjured up in the film's first half, and their spectral emptiness in the "now" of the frame-story serves as a measure of the loss that historical events will visit upon this family, and by extension, upon the peasant community for which it stands. Because the opening spectacle of empty rooms and abandoned beds hovers over our consciousness during the course of the film, the return to this scene at the end of The Man Who Will Come sets up an internal system of memory-a déjà $v u$ which brings the framestory back to its starting point, but with one crucial difference. In the concluding replay of the film's opening fragment, Martina's bed remains empty-there is no earlier self to occupy the bed, and to start the story again. Now it is up to Martina to symbolically fill that emptiness through the excruciating, but absolutely necessary act, of bearing witness. And it is up to us to receive her testimony by accepting the moral charge of Diritti's film: "I morti di Marzabotto hanno un solo perchè possible-che in futuro una cosa del genere non venga più" (the dead of Marzabotto have only one possible 'because'- that in the future something like this never happen again). ${ }^{25}$

\section{Yale University}

24 "Cronaca di una strage per non dimenticare," in Uomini d'ogni tempo, 46. ${ }^{25}$ From the interview with Barbara Sorrentini included on the Dolmen Home Video DVd. 
The Man Who Will Come (2009)

Title in Italian

Directed by

Screenplay by

Photography by

Music by

Edited by

Sound by

Sets by

Costumes by

Played by

Martina

Lena

Beniamina

Armando

Maria

Vittoria

Dino

Antonio

Signor Bugamelli

Signora Bugamelli

Merchant

Pepe

Partigiano Gianni

Dante

Don Ubaldo Marchioni

Don Giovanni Fornasini

SS medical officer

SS officer

Wehrmarcht Officer

SS Captain
L'uomo che verrà

Giorgio Diritti

Giorgio Diritti, Giovanni Galavotti, Tania Pedroni

Roberto Cimatti

Marco Biscarini, Daniele Furlati

Giorgio Diritti, Paolo Marzoni

Carlo Missidenti

Giancarlo Basili

Lia Francesca Morandini
Greta Luccheri Montanari

Maya Sansa

Alba Rohrwacher

Claudio Casadio

Laura Pizzirani

Maria Grazia Naldi

Stefano Croci

Francesco Modugno

Stefano "Vito" Bicocchi

Eleonora Mazzoni

Orfeo Orlando

Diego Pagotto

Bernardo Bolognesi

Zoello Gilli

Germano Maccioni

Raffaele Zabban

Timo Jacobs

Tom Sommerlatte

Frank Schmalz

Thaddaeus Meilinger

\section{Works Consulted}

Anselmi, Michele. Review of The Man Who Will Come. Ciak, 2 February 2010: 78. Antonello, Pierpaolo and Florian Mussgnug, eds. "Introduction," Postmodern 'Impegno': Ethics and Commitment in Contemporary Italian Culture. Oxford: Peter Lang, 2009. 1-29.

Arnone, Gianluca. "The Man Who Will Come: Rigore stilistico e morale per raccontare la strage di Marzabotto. Film civile, non politico." Rivista del cinematografo, 1-2, January-February 2010: 68.

Bakhtin, Mikhail. The Dialogic Imagination. Ed. Michael Holquist. Trans. Caryl Emerson and Michael Holquist. Austin: University of Texas Press, 1981. 206224. 
Basso, Daniela, “The Man Who Will Come? Intervista con Giorgio Diritti.” Ed. Daniela Basso, Uomini d'ogni tempo. Milan: Feltrinelli, 2010. 22-33.

Chiesi, Roberto, 'Un film 'inattuale.' The Man Who Will Come di Giorgio Diritti, Cinemasessanta 303 January-March 2010: 6-8.

Review of The Man Who Will Come. Segnocinema 30 March-April 2010: 33-4.

Coco, Attilio. "La trasparenza della Storia," Segnocinema 30 March-April 2010: 34.

D’Agostini, Paolo. "Cronaca di una strage per non dimenticare." Uomini d'ogni tempo.Ed. Daniela Basso. Milan: Feltrinelli, 2010. 45-6

Diritti, Giorgio. "Sul set." Ciak January 2010: 108-113.

"The Man Who Will Come: Un film su Monte Sole, Uomini d'ogni tempo.Ed. Daniela Basso. Milan: Feltrinelli, 2010. 9-12

Elia, Eliana. Review of "The Man Who Will Come." Segnocinema 30 SeptemberOctober 2010: 74-5.

Ferzetti, Fabio, “Tante emozioni per soffiar via la polvere della Storia.” Uomini d'ogni tempo. Ed. Daniela Basso. Milan: Feltrinelli, 2010. 55-6

Fofi, Goffredo, "Prima e dopo la strage." Uomini d'ogni tempo. Ed. Daniela Basso,. Milan: Feltrinelli, 2010. 13-15

Freud, Sigmund. "Mourning and Melancholia." The Standard Edition of the Complete Psychological Works of Sigmund Freud, vol. 14. Trans. and ed. James Strachey. London: Hogarth Press, 1953-74. 237-258

Mereghetti, Paolo. "Il diario della strage e gli umili." Uomini d'ogni tempo. Ed. Daniela Basso. Milan: Feltrinelli, 2010. 52-54

Pavone, Claudio. “Diritti: The Man Who Will Come." Ed. Daniela Basso. Milan: Feltrinelli, 2010. 34-5

Pedroni, Federico. Review of The Man Who Will Come. Duellanti 59 February 2010:17.

Santner, Eric. "History Beyond the Pleasure Principle: Some Thoughts on the Representation of Trauma." Probing the Limits of Representation: Nazism and the 'Final Solution.' Ed. Saul Friedlander. Cambridge, MA: Harvard University Press, 1992. 143-154

Simili, Bruno, “Quell'aspra bellezza del film di Diritti." Uomini d'ogni tempo. Ed. Daniela Basso. Milan: Feltrinelli, 2010. 60-1

Sorrentini, Barbara. Interview. Dolmen Home Video DVD (2010). 